\title{
USING CROWDFUNDING AS PART OF THE PRODUCT DEVELOPMENT PROCESS
}

\author{
H. Forbes ${ }^{凶}$, J. Han and D. Schaefer \\ University of Liverpool, United Kingdom \\ $\varangle$ hannah.forbes@liverpool.ac.uk
}

\begin{abstract}
Crowdfunding is the process of taking a project in need of investment and asking a large group of people to supply the investment. It allows organisations to sell their product before production, reducing the risk of new product development. Organisations such as Tesla and General Electric have used crowdfunding successfully but crowdfunding is yet to be explored as part of a formalised product development framework. This paper includes the business case for commercialising new products with crowdfunding and presents crowdfunding as part of a product development and commercialisation framework.
\end{abstract}

Keywords: crowdfunding, crowdsourcing, product development, open innovation, business models

\section{Introduction}

Literature on new product development is extensive with many researchers proposing new ways to improve and innovate the process. Crowdfunding, however, is a relatively new phenomenon and is yet to be considered in this context. Crowdfunding offers the opportunity to get product feedback, test product demand before market launch and requires no committed spend on manufacturing prior to collection of funds. For these reasons it offers a vehicle for innovation, allowing organisations to explore new markets and test new products with significantly reduced risk. This section introduces crowdfunding and the four different models of crowdfunding.

\subsection{The definition of crowdfunding}

The term crowdfunding is not yet well-understood in its entirety and breadth. This is likely as a consequence of the growing recognition of modern crowdfunding being proliferated with the emergence of platforms such as Kickstarter and Indiegogo. This has caused crowdfunding to be generally understood as the process of exposing a product to the public, using an online platform; seeking investment in return for rewards (Forbes and Schaefer, 2017). This definition, however, does not represent the several other forms of crowdfunding.

While Kickstarter was actually developed to finance creative ventures, (McCracken, 2012) its income comes predominantly from products within technology and design (Maron et al., 2015). This has led to a natural association of crowdfunding with hardware, but events, personal ventures and businesses are all open to the crowdfunding model (Chafkin, 2013). Furthermore, the return on an investment can be in the form of a prototype, a gift, an equity stake (Freedman and Nutting, 2015) or in many circumstances, the contributor donates with no expectation of return (Tomczak and Brem, 2013). 
Furthermore, while crowdfunding is a phenomenon that has erupted through online integration, crowdfunding can exist both on and offline (Belleflamme et al., 2014). Finally, the project creator does not necessarily have to expose their campaign to the public as campaigns can be directed to a targeted set of users using private platforms (Frydrych et al., 2014). Founders may choose to do this if their idea requires patenting, or to engage with potential backers on a more personal level (Maron et al., 2015). To ensure all forms of crowdfunding are encompassed, the following definition is presented; crowdfunding is defined as the process of taking a project, or business, in need of investment and asking a large group of people to supply this investment.

\subsection{The four models of crowdfunding}

Belleflamme et al. (2014) initially considered the concept of "crowdfunding models" by outlining two overarching types of crowdfunding, which are "profit-sharing" and "pre-ordering". Pre-ordering is the crowdfunding initiative that encourages individuals to fund a project, in return for early access to the project's results (Belleflamme et al., 2014). A platform that famously endorses this model is Kickstarter (Forbes and Schaefer, 2017). The profit-sharing model, or equity crowdfunding, is most similar to traditional investment models. The investor funds a venture in return for a small stake in the business (Maron et al., 2015). In a traditional setting, this may see a business angel take a $20 \%$ stake, while in crowdfunding this may see one thousand individuals each take a $0.02 \%$ stake in the business (Freedman and Nutting, 2015).

As a rapidly changing industry, the categorisation of crowdfunding models can no longer be restricted to these two terms. Profit-sharing or, as it is now known, equity crowdfunding is its own distinct model. Pre-ordering, however, now exists as a subset of another modern model known as rewardsbased crowdfunding (Frydrych et al., 2014). Frydrych et al. (2014) state; "rewards-based crowdfunding projects commonly have pre-order mechanisms integrated into their reward structure".

Two further models exist in modern crowdfunding. These are donation-based crowdfunding and lendingbased crowdfunding (Frydrych et al., 2014). Donation-based crowdfunding generates contributions from backers that have no expectation of a return (Maron et al., 2015). The lending-based model is a crowdfunding initiative that allows users to essentially loan money from the public (Forbes and Schaefer, 2017). Many members of the public consolidate their funds to create a loan which is made available, using a crowdfunding platform, such as The Funding Circle (2019). The return, as well as the risk of nonrepayment, is spread across the contributors as opposed to a single lender (Bruton et al., 2015).

The further sections of this paper refer only to rewards-based crowdfunding, represented by platforms such as Kickstarter (2019) and Indiegogo (2019). This is because rewards-based crowdfunding is the only model that incorporates gifting prototypes as part of the crowdfunding process (Forbes and Schaefer, 2017) and therefore most relevant to product development organisations. Equity and lending-based are most appropriate for pre-seed investment organisations and donation based is most appropriate for charitable causes (Mollick, 2014). Further sections refer only to rewards-based crowdfunding and its benefit to product development organisations.

\subsection{Paper aim}

This paper makes a contribution by examining crowdfunding as a tool for product development organisations, as opposed to new businesses. Furthermore, it includes insight into how and when crowdfunding can be applied in a traditional product development process. The authors specifically address the research question; How and when can crowdfunding be used in the product development process? By doing so, they are addressing an important research gap in both the crowdfunding and product development sectors, offering new opportunities in product development to innovate, market and commercialise new products.

\section{Existing literature on crowdfunding and product development}

Rewards-based crowdfunding is now a significant industry with Kickstarter recently announcing over three billion in funding raised on the platform. General literature on rewards-based crowdfunding is therefore not scarce but there is limited literature that references the product development process. The literature on this subject can be segmented into three sectors; literature presenting the benefits of crowdfunding in product 
development, literature presenting findings on the success of crowdfunded products in market and literature suggesting where crowdfunding can fit in the product development process.

Of these sectors, the former is the most populated with the significant majority of the gathered literature, describing the benefits of crowdfunding in product development. Stanko and Henard (2016) discuss the impact of rewards-based crowdfunding on product innovation. They highlight the nonfinancial benefits of crowdfunding including "building brand awareness", "promoting word of mouth marketing" and receiving "valuable product feedback". They also suggest that crowdfunding campaigns entice "engaged early adopters" to the organisation that become "great evangelists" for the product (Stanko and Henard, 2016). Products that include crowdfunding in their development process, according to Mollick (2014), create "higher quality products" and "build a stable community around a product". Furthermore, it is an excellent way to "attract attention from your trade" with many new product businesses, gaining further funding after a successful campaign. Stanko and Henard (2016) also refer to the marketing benefits of a crowdfunding campaign stating that campaigns allow product developers to "join a broader conversation with large numbers of potential customers". This sector therefore makes an excellent business case for crowdfunding for products, with academics consistently stating both the financial and non-financial benefits of crowdfunding for product development. These benefits, however, are only considered from a new business perspective and crowdfunding for larger organisations is rarely explored. Furthermore, the vast majority of this literature aims to draw new insights for the crowdfunding industry as opposed to the product development industry. As a consequence, the perspective of the product development organisation is rarely considered.

The second sector of literature considers crowdfunding as a commercialisation tool for products and presents findings on improved market performance of crowdfunded products. Hu et al. (2015) suggest that crowdfunding may result in more revenue per unit "compared with the traditional setting" of market selling. This is a consequence of the "herd mentality" fuelled by increasing sales number being exposed to potential backers. Product creators normally make several "reward options" available for selection (Forbes and Schaefer, 2017) and, providing the pricing strategy is effective, backers often are shown to spend more than market value on popular reward options (Hu et al., 2015). Furthermore, Hu et al. (2015) have found that products that have been successfully crowdfunded have a "higher perceived value" when taken to market (Ho et al., 2014). Furthermore, Belleflamme et al. (2014) discuss the economics of crowdfunding and how crowdfunding allows product creators to "price discriminate between two groups of consumers"; crowdfunding consumers and non-crowdfunding consumers. By doing so Belleflamme et al. (2014) claim they are able to extract larger profits (Belleflamme et al., 2014). In addition, Schwienbacker and Larralde (2010) state that crowdfunding "can provide valuable signals on the market potential of the product" and suggest there are longer-term benefits of crowdfunding products as "the crowd may become further consumers". They emphasise the "public attention (creators) may get and validation for their product before bringing it to market". This literature sector alludes to the benefit of crowdfunding for commercialisation, but the product development process is not thoroughly considered. The literature sector also omits the consideration of more established organisations and focuses on the benefits for new product-based businesses.

The final sector intersects most significantly with the research included in this paper. In a few papers, the role and place of crowdfunding in the product development process is considered. Stanko and Henard (2016) state that crowdfunding can "improve and accelerate the product development process" and allows backers to "observe and provide input into the development and commercialisation" of products. They also present findings that suggest that creators should use crowdfunding in the "early stages of product development" and use it to "reduce risk in new product development and manufacturing". Chemla and Tinn (2018) offer the most insight into crowdfunding in product development by presenting "a model where rewards-based crowdfunding enables firms to obtain a reliable proof of concept early in their production cycle". By doing so, they demonstrate the benefit of using crowdfunding in early design phases. Similarly, Feldmann et al. (2014) present an initiative called "enterprise crowdfunding" which includes using crowdfunding as a tool for concept evaluation. Ideas for new products are presented to employees and the employees invest in the ideas they think has the most potential. Finally, Stanko and Henard (2016) suggest that crowdfunding should be used after the detailed design phase and before production to fund larger production runs and "keep unit 
costs as low as possible". While information provided by this literature is valuable in determining the role of crowdfunding in product development, a thorough examination of crowdfunding as part of the product development process does not yet exist. As a consequence, there is no clear guidance on how and when to apply crowdfunding in product development. Furthermore, as with previous literature sectors, the challenges and opportunities for established organisations are not considered.

\section{Methodology}

The first activity in the framework creation process was to select an existing design method to adapt to include crowdfunding. By including crowdfunding in a familiar process, this new knowledge is more easily applicable and useful for practitioners.

An input-output analysis was used to integrate crowdfunding into the selected product development process. In this case, inputs refer to the requirements of the activity and outputs refer to the product of the activity. Input-output analyses have been used by several authors in the adaptation of design methods. Bilgili et al. (2011) apply the Kano Model to existing design processes by consolidating the "demands and requirements" of each activity while Lindemann et al. (2002) encourage "modelling object relations, according to dependencies", for adaptation of design methods. Prösser et al. (2013) also adopt this analysis process to repurpose current workflow systems for complex engineering design tasks. All authors therefore considered inputs and outputs of each design phase to integrate new activities into traditional design processes, this method has therefore been conducted in this paper.

\section{Selecting a meso-procedural design method}

The purpose of this research was to create a product development process, including crowdfunding, that could be understood and applied by practitioners. As a consequence, the first step was to determine which product development process should be adapted for this purpose. The product development process has been depicted in several ways, but the authors were most interested in the diagrammatic representation of product development that most accurately represented how established organisations design products. To determine this, existing literature on this subject was consulted.

Wynn and Clarkson (2018) provide a comprehensive list of all well-known product development methods. To select between these methods for practise in industry, Lindström et al. (2013) suggest several selection criteria are used, such as quality of assurance, traceability and cost effectiveness. In reality, however, Gericke et al. (2016) suggest that practitioners choose their selection method based solely on efficacy i.e. the ability of the design method to produce the desired result. Furthermore, Araujo et al. (1996) suggest that design methods are rarely chosen in a methodical way and design methods are often adapted from the existing theoretical processes the exist in academia. As a consequence, it is very difficult to accurately choose a single design method to represent product development in practise. Instead, the authors referred to information provided by Wynn and Clarkson (2018) on the "suitability for implementation" of their outlined design methods.

Wynn and Clarkson (2018) state that "procedural models convey best practise intended to guide real world situations" and that while in practise, design methods are evolved, they are usually "evolved from procedural models to meet their needs". Having selected procedural methods as the most appropriate method for this task, the level of abstraction was then to be considered. Micro-level procedural methods are shown to apply to only single phases of the design process, while macro-level procedural methods are for organisational-level planning (Wynn and Clarkson, 2018). López-Mesa and Bylund (2011) discuss design method use for different strategy levels in business. They state that at the "organisational level", methods for business strategy and market capture are most appropriate while at the "operational level" procedural methods presenting the different design phases are most used in practise. While the use of crowdfunding is likely to involve organisational-level decision making, practitioners at the operational level are those required to understand when and how crowdfunding should be used. As a consequence, neither macro-level nor micro-level procedural methods are appropriate, and a meso-level procedural method is presented for this activity. Figure 1 below shows the product development process, used to represent product development in industry, that will be adapted to include crowdfunding. 


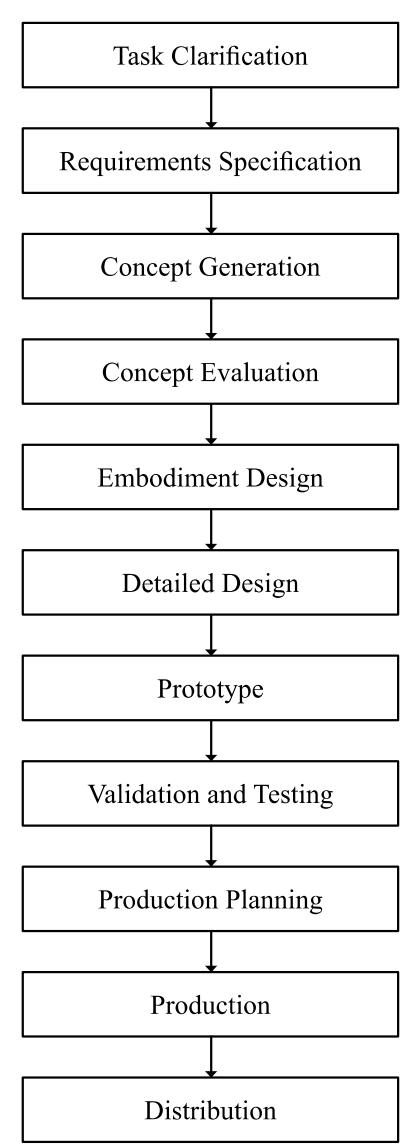

Figure 1. The meso-procedural design method representing the process of product development in industry (Pahl and Beitz, 1996)

\section{Integrating crowdfunding into the product development process}

To adapt the product development process shown in Figure 1 an input-output diagram for each phase was formed using existing literature. An input-output analysis was then performed to determine when crowdfunding can be used in the product development process.

\subsection{Deriving inputs and outputs}

The first stage in deriving an integrated crowdfunding and product development process was identifying the key inputs and outputs for the crowdfunding process. Existing literature in the alternative finance sector is extensive in describing the requirements for a successful crowdfunding campaign. The authors used search terms including "factors for crowdfunding success", "requirements for crowdfunding success", "guidelines for crowdfunding success" and "crowdfunding benefits" to yield the following papers outlining the key inputs and outputs:

- Crowdfunding support tools: predicting success and failure, Greenberg et al. (2013)

- Guidelines for successful crowdfunding, Forbes and Schaefer (2017)

- The dynamics of crowdfunding: an exploratory study, Mollick (2014)

- The determinants of crowdfunding success: evidence from technology projects, Cordova et al. (2015)

- Dynamic strategies for successful online crowdfunding, Li and Duan (2014)

- Strategic approaches to successful crowdfunding, Assadi (2015)

- Strategies for rewards-based crowdfunding campaigns, Kraus et al. (2016)

Papers were selected if they explicitly stated requirements or results of a successful crowdfunding process. This yielded 7 papers stating 7 inputs and 7 outputs. 


\subsection{Input-output diagrams}

Table 1 shows the input-output diagrams and design decisions associated with each design phase shown in Figure 1. Figure 2 below shows the input-output diagram for the crowdfunding process. In Figure 2, the "crowdfunding process" block is a black box representing the multi-staged crowdfunding process. The inputs are shown on the left-hand side of the diagram with the outputs on the right.



Figure 2. Input-output diagram for the crowdfunding process

\subsection{Synthesis}

Crowdfunding platforms require a proof of principle prototype to be demonstrated on the campaign. As a consequence, a crowdfunding campaign cannot be launched until this phase is completed (Kickstarter, 2019) and phases prior to the prototyping stage cannot benefit from crowdfunding outputs. Outputs from these early phases, however, can allow preparation for a campaign to begin and the work required in these phases may be adjusted to accommodate crowdfunding in the product development process. Each phase was compared with the crowdfunding diagram Figure 2 and suggested adjustments to the development process were given.

Many of the outputs from task clarification, product requirements specifications, concept generation and concept evaluation act as inputs for the crowdfunding process. Specifically, the market research required to construct the product requirements specification, provides important information on how to construct the crowdfunding campaign. Furthermore, a crowdfunding campaign requires evidence of the product development process and outputs from task clarification, concept generation and concept evaluation such as the business case for the product and product sketches are important to include in the campaign (Forbes and Schaefer, 2017). This is also the case for embodiment design and detailed design with technical drawings and models demonstrating the robustness of the product's design.

Having progressed to the output of the proof of principle prototype, all but one input for the crowdfunding campaign is prepared. A production plan for a crowdfunding campaign is required firstly, to give potential backers an expected delivery time. Secondly, an estimated cost of production is required to ensure the funding goal is set at an appropriate value (Forbes, 2016). The crowdfunding process can then be initiated after the production plan is completed.

The inputs for the validation and testing phase include the testing process, the testing tools and further funding. Crowdfunding, when included in the product development process, behaves as the testing process and tools, and requires no further funding. The outputs of the crowdfunding process include market validation and product feedback and therefore the crowdfunding process replaces this phase. The pricing strategy for the crowdfunding campaign, however, should be included as part of the market research conducted during the product requirements specification (Forbes, 2016). This research should also result in a marketing strategy including the other non-product reward options that should be available to contributors. The funding required for the production process is provided by the crowdfunding campaign and distribution is also managed as part of the crowdfunding process, with the distribution channels being managed as part of the campaign. To clarify this process, the crowdfunding process has been split into "campaign" and "delivery" phases. These adjustments to the product development process are illustrated in Figure 3 below. To clearly illustrate these changes, only the inputs and outputs relevant to the crowdfunding process are included in this figure. 
Table 1. Input-output diagrams and design decisions for the meso-procedural product development process

\begin{tabular}{|c|c|c|c|}
\hline \multicolumn{3}{|c|}{ Input-output diagram } & Design Decisions \\
\hline $\begin{array}{r}\text { Design Team } \\
\text { Design Task } \\
\text { Knowledge on market } \\
\text { Funding }\end{array}$ & $\rightarrow$ Task Clarification & 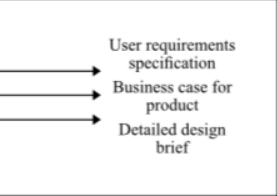 & $\begin{array}{l}\text { 1. What are the objectives that the intended solution is } \\
\text { expected to satisfy? } \\
\text { 3. What problem is being solved? }\end{array}$ \\
\hline $\begin{array}{l}\text { Competition Analysis } \\
\text { Market research } \\
\text { Standards }\end{array}$ & $\begin{array}{l}\text { Product Requirements } \\
\text { Specifications }\end{array}$ & 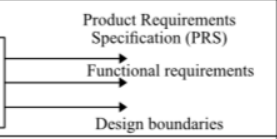 & $\begin{array}{l}\text { 1. Within what design boundaries are we operating? } \\
\text { 2. What are our functional requirements? }\end{array}$ \\
\hline Generation techniques & Concept Generation & 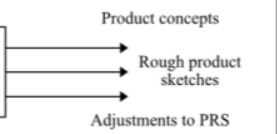 & $\begin{array}{l}\text { 1. Present concepts within the design boundaries } \\
\text { 2. Present concept that meet the functional requirements }\end{array}$ \\
\hline Evaluation techniques & Concept Evaluation & $\longrightarrow \begin{array}{c}\text { One or two product } \\
\text { concepts }\end{array}$ & $\begin{array}{l}\text { 1. Feasibility analysis on concepts } \\
\text { 2. Which of these concepts fulfils our requirements? } \\
\text { 3. Are any adjustments to the PDS required? }\end{array}$ \\
\hline Embodiment design tools & Embodiment Design & 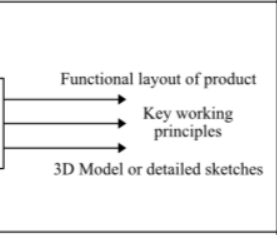 & $\begin{array}{l}\text { 1. What are the dimensions? } \\
\text { 2. How does this product fulfil the PDS? } \\
\text { 3. What are the components? } \\
\text { 4. What is our final solution? }\end{array}$ \\
\hline $\begin{array}{l}\text { Further funding } \\
\text { Modelling Tools } \\
\text { Drawing Tools }\end{array}$ & Detailed Design & \begin{tabular}{|}
$\underset{\text { CAD Model }}{\stackrel{\text { Dssetailed Drawings }}{\longrightarrow}}$ \\
$\underset{\longrightarrow}{\longrightarrow}$ drawings
\end{tabular} & $\begin{array}{l}\text { 1. What are the exact dimensions of all components } \\
\text { 2. What is the assembly of the product? } \\
\text { 3. What materials are the components made of? }\end{array}$ \\
\hline $\begin{array}{l}\text { Further funding } \\
\text { Materials } \\
\text { Off-the-shelf } \\
\text { components } \\
\text { Manufacturing } \\
\text { space }\end{array}$ & Prototype & $\rightarrow \begin{array}{c}\text { Proof of principle } \\
\text { prototype }\end{array}$ & $\begin{array}{l}\text { 1. How can the function of the product be demonstrated? } \\
\text { 2. What materials should be used? } \\
\text { 3. What manufacturing processes should be used? }\end{array}$ \\
\hline $\begin{array}{l}\text { Testing process } \\
\text { Testing tools } \\
\text { Further funding }\end{array}$ & Validation and Testing & $\begin{array}{r}\stackrel{\text { Market research }}{\longrightarrow} \text { Pricing strategy } \\
\text { Product feedback }\end{array}$ & $\begin{array}{l}\text { 1. Does the product perform as expected? } \\
\text { 2. Do the users interact with the product as expected? } \\
\text { 3. Do the users like the product? } \\
\text { 4. What improvements are required? }\end{array}$ \\
\hline $\begin{array}{l}\text { Supplier } \\
\text { searching tool } \\
\text { Account } \\
\text { management process } \\
\text { Further funding }\end{array}$ & Production Planning & 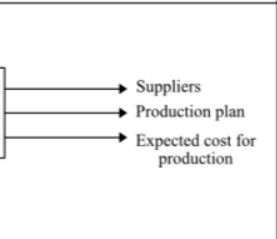 & $\begin{array}{l}\text { 1. How many units per batch? } \\
\text { 2. What materials to be used? } \\
\text { 3. What manufacturing process to be used? } \\
\text { 4. What supplier can fulfil our production demands? }\end{array}$ \\
\hline $\begin{array}{l}\text { Significant } \\
\text { funding }\end{array}$ & Production & $\longrightarrow$ Products & $\begin{array}{l}\text { 1. When should production begin? } \\
\text { 2. How often should products be produced? }\end{array}$ \\
\hline $\begin{array}{l}\text { Further funding } \\
\text { Marketing Strategy } \\
\text { Branding } \\
\text { Distribution Channels } \\
\text { Packaging supplier }\end{array}$ & Distribution & $\underset{\text { Product feedback }}{\stackrel{\text { Sales from product }}{\longrightarrow} \text { rand awareness }}$ & $\begin{array}{l}\text { 1. What distribution channels should be used? } \\
\text { 2. How much should be charged for postage and } \\
\text { packaging? } \\
\text { 3. How should our product be branded and marketed? }\end{array}$ \\
\hline
\end{tabular}




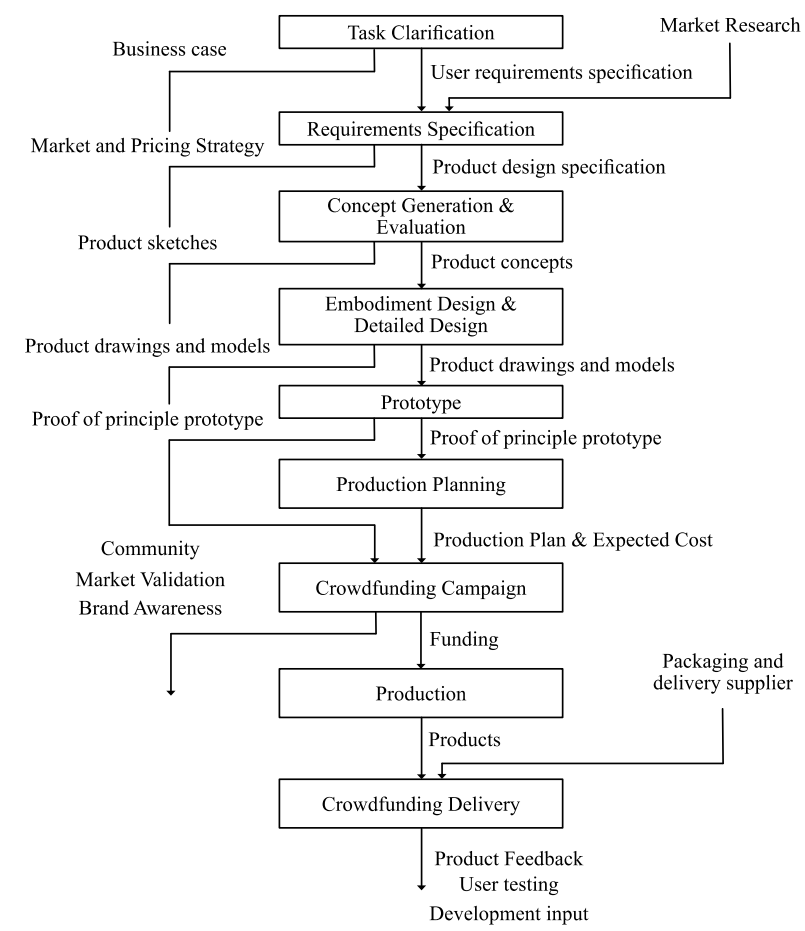

Figure 3. The adapted meso-procedural product development process including crowdfunding

\section{Discussion}

The diagram shown in Figure 3 is an adapted meso-procedural product development process incorporating preparation, launch and delivery of a crowdfunding campaign. The diagram first provides practitioners with an understanding of the key crowdfunding activities required to prepare for, launch and deliver a crowdfunding campaign, in the context of product development. Most significantly, it also indicates when in the product development process these activities should be initiated and how they are used for the preparation of the crowdfunding campaign. As a consequence, product development practitioners gain an understanding of how key product development activities intersect with crowdfunding activities which ultimately provides valuable support for project management and planning. Furthermore, this diagram demonstrates how both product value and business value is created throughout the process, which offers insights for commercialisation methods of several kinds. For example, Figure 3 includes activities such as market research and pricing which are vital business activities irrespective of the route to market.

Limitations of this model include the idealistic presentation of the design process, its high-level of abstraction and the assumption of crowdfunding knowledge. Firstly, as stated by Eder et al. (1998), design methods are often too rigid for industrial use and "even the individual 'industry best practise' methods are each used in only a small fraction of industry". While organisations often consider new methods for ideation (Birkhofer et al., 2005), for embodying and elaborating experience knowledge is relied upon, as opposed to design theory (Eder et al., 1998). it is therefore the case that prescriptive design approaches, such as the one presented in Figure 3, are rarely adopted in industry. Frost et al. (1999) suggest design methods require an underlying understanding of design theory which many practitioners lack and Eder et al. (1998) state that design methods "must be adapted to that organization, usually by members of that organization - they must have 'ownership' of the method, and adapting and championing a method is a difficult task". Crowdfunding knowledge may be more effectively transferred to industry through consultancy.

Secondly, the framework presented in Figure 3 is of a high-level of abstraction. While this allows easier application and adaptation by practitioners, for a new activity such as crowdfunding, this may limit the value of the framework. Crowdfunding is a poorly understood process (Forbes and Schaefer, 2017) and high-level guidance such as "build a community" may not adequately support product development practitioners. It may be particularly difficult to action some of these activities by those 
with limited understanding of business and marketing principles. A further limitation, therefore, is the requirement of some business and marketing knowledge. In larger organisations, product development practitioners may be supported by a distinct marketing department, but in the case of start-ups or SMEs, some activities in Figure 3, may be difficult to complete.

To address these limitations, the authors plan several further research avenues. The first is to consult organisations that are most interested and most viable for the use of crowdfunding. Organisations with consumer-facing products are more likely to achieve crowdfunding success by offering a value proposition that appeals to a wider audience (Forbes and Schaefer, 2017). The authors therefore plan to consult these organisations, examine their standard product development practises, and consider how crowdfunding would be best integrated into these processes. Furthermore, the authors plan to incorporate more detailed guidance into this framework, leveraging research from other fields that present guidelines for crowdfunding success outside the context for product development (Mollick, 2014; Stanko and Henard, 2016; Schwienbacher and Larralde, 2010). This will increase the accessibility of the framework by reducing the amount of assumed crowdfunding knowledge. Finally, the authors plan to conduct empirical research to validate the crowdfunding framework. By using the framework to guide a new product development process, its value to practitioners will be more clearly demonstrated.

\section{Conclusions}

Despite benefits to product development organisations, crowdfunding is yet to be presented as part of the product development process. The aim of this paper was to present a product development and commercialisation process that integrated crowdfunding. Specifically, the authors aimed to present a product development and commercialisation process familiar to established organisations, a perspective yet to be considered in literature. To recognise the perspective of established organisations, several stages of evaluation of existing product development methods was conducted, arriving at a meso-procedural method most suitable for industrial application. Using an input-output analysis, the authors integrate crowdfunding preparation, launch and delivery activities into this mesoprocedural design method resulting in a design method that guides traditional product development activities alongside crowdfunding activities, offering valuable insights for project management and planning. Furthermore, since limited guidance for crowdfunding within a product development context exists, this framework also provides valuable information for practitioners on the key activities for crowdfunding success. Limitations of the framework include its high-level of abstraction, its idealistic presentation of the design process and the assumption of crowdfunding knowledge. Further work including validation of the framework has been proposed by the authors.

\section{References}

Araujio, S.C. et al. (1996), "The utilization of product development methods: a survey of UK industry", Journal of Engineering Design, Vol. 7 No. 3, pp. 265-277. https://doi.org/10.1080/09544829608907940

Assadi, D. ed., (2015). Strategic approaches to successful crowdfunding. pp. 12-14, pp. 17-23 IGI Global.

Belleflammer, P., Lambert, T. and Schwienbacher, A. (2014), "Crowdfunding: Tapping the right crowd", Journal of business venturing, Vol. 29 No. 5, pp. 585-609. http://dx.doi.org/10.1016/j.jbusvent.2013.07.003

Bilgili, B., Erciş, A. and Ünal, S. (2011), "An extensive and detailed view of the application of design methods and methodology in industry", Procedia-Social and Behavioral Sciences, Vol. 24 No. 1, pp. 829-846. https://doi.org/10.1016/j.sbspro.2011.09.058

Birkhofer, H., Jänsch, J. and Kloberdanz, H. (2005), "An extensive and detailed view of the application of design methods and methodology in industry", Proceedings of the ICED 05 / 15th International Design Conference on Engineering Design, Melbourne, Australia, August 15-18, 2005, The Design Society, Glasgow, pp. 276-277.

Bruton, G. et al. (2015), "New financial alternatives in seeding entrepreneurship: Microfinance, crowdfunding, and peer-to-peer innovations" Entrepreneurship Theory and Practice, Vol. 39 No. 1, pp. 9-26. https://doi.org/10. 1111/etap.12143

Chafkin, M. (2013), "Kickstarter can fund your dreams", Fast Company, pp. 92-115.

Chemla, G. and Tinn, K. (2014), "Learning through Crowdfunding” Journal of Management Science pp. 37-42. https://doi.org/10.1016/j.jbusvent.2013.06.005 
Cordova, A., Johanna D. and Gianfranco G. (2015) "The determinants of crowdfunding success: evidence from technology projects.” Procedia-Social and Behavioral Sciences Vol. 181, pp. 115-124.

Eder, W.E. (1998), "Design modeling-a design science approach (and why does industry not use it?)". Journal of Engineering Design, Vol. 9 No. 4, pp. 355-371. https://doi.org/10.1080/095448298261499

Feldmann, N. et al. (2014), Idea assessment via enterprise crowdfunding: An empirical analysis of decisionmaking styles, pp. 91-95, Springer, Berlin.

Forbes, H. (2016), Understanding Crowdfunding: Constructing a Guidance Tool for Success, [Thesis], University of Bath. pp. 37-59.

Forbes, H. and Schaefer, D. (2017), “Guidelines for successful crowdfunding”, Procedia CIRP 2017 / 27th CIRP Design Conference, Milton Keynes, England, May 10-12, 2017, pp. 398-403. https://doi.org/10.1016/j. procir.2017.02.021

Freedman, D.M. and Nutting, M.R. (2015), “The Growth of Equity Crowdfunding”, Value Examiner, pp. 6-10.

Frost, R.B. (1999), "Why Does Industry Ignore Design Science?”, Journal of Engineering Design, Vol. 10 No. 4, pp. 301-304. https://doi.org/10.1080/095448299261218

Frydrych, D. et al. (2014), "Exploring entrepreneurial legitimacy in reward-based crowdfunding", Venture Capital, Vol. 16 No. 3, pp. 247-269. https://doi.org/10.1080/13691066.2014.916512

Gericke, K., Kramer, J. and Roschuni, C. (2016), "An exploratory study of the discovery and selection of design methods in practice", Journal of Mechanical Design, Vol. 138 No. 10, p. 101109. https://doi.org/ $10.1115 / 1.4034088$

Greenberg, M.D. et al. (2013). "Crowdfunding support tools: predicting success \& failure”. In CHI'13 Extended Abstracts on Human Factors in Computing Systems pp. 1815-1820.

Ho, H.Y., Lin, P.C. and Lu, M.H. (2014), "Effects of online crowdfunding on consumers' perceived value and purchase intention" The Anthropologist, Vol. 17 No. 3, pp. 837-844. https://doi.org/10.1080/09720073. 2014.11891498

Hu, M., Li, X. and Shi, M. (2015), "Product and pricing decisions in crowdfunding" Marketing Science, Vol. 34 No. 3, pp. 331-345. https://doi.org/10.1287/mksc.2014.0900

Indiegogo (2019), Indiegogo [online] Indiegogo. Available at: https://indiegogo.com (accessed 12.10.2019).

Kickstarter (2019), Kickstarter [online] Kickstarter. Available at: https://kickstarter.com (accessed 12.10.2019).

Kraus, S. et al. (2016). Strategies for reward-based crowdfunding campaigns. Journal of Innovation \& Knowledge, Vol. 1 No. 1, pp. 13-23.

Li, Z. and Duan, J.A. (2014). Dynamic strategies for successful online crowdfunding, No. 14-09, pp. 3012-3015.

Lindemann, U. (2002), "Flexible adaptation of methods within the design process", Proceedings of DESIGN 2002 / 7th International Design Conference, Dubrovnik, Croatia, May 15-18, 2025, The Design Society, Glasgow, pp. 1022-1027.

Lindström, J. et al. (2013), "Functional product development: criteria for selection of design methods on strategic and operational levels", The Philosopher's Stone for Sustainability, pp. 25-30. https://doi.org/10. 1007/978-3-642-32847-3_4

López-Mesa, B. and Bylund, N. (2011), "A study of the use of concept selection methods from inside a company", Research in Engineering Design, Vol. 22 No. 1, pp. 7-27. https://doi.org/10.1007/s00163-010-0093-2

Maron, D., Grell, K. B and Swart, R. (2015), Crowdfunding: The Corporate Era, Elliott \& Thomspon, London.

McCracken, H. (2012), The Kickstarter Economy, Time, London. Vol. 180, pp. 32-36.

Mollick, E. (2014), “The dynamics of crowdfunding: An exploratory study" Journal of business venturing, Vol. 29 No. 1, pp. 1-16. https://doi.org/10.1016/j.jbusvent.2013.06.005

Pahl, G. and Beitz, W. (1996). Engineering a Systematic Approach.

Prösser, M. et al. (2013), "A new approach towards systems integration within the mechatronic engineering design process of manufacturing systems", International Journal of Computer Integrated Manufacturing, Vol. 26 No. 8, pp. 806-815. https://doi.org/10.1080/0951192X.2013.785026

Scholz, N. (2015), The relevance of Crowdfunding: The impact on the innovation process of small entrepreneurial firms, Springer, Berlin, pp. 123-135. https://doi.org/10.1007/978-3-658-09837-7

Schwienbacher, A. and Larralde, B. (2010), Crowdfunding of small entrepreneurial ventures, Oxford University Press, Oxford. pp. 2013-2017. http://dx.doi.org/10.2139/ssrn.1699183

Stanko, M.A. and Henard, D.H. (2016), "How crowdfunding influences innovation" MIT Sloan Management Review, Vol. 57 No. 3, p. 15.

The Funding Circle (2019), The Funding Circle [online] The Funding Circle. Available at: https://fundingcircle.com (accessed 12.10.2019)

Tomczak, A. and Brem, A. (2013), “A conceptualized investment model of crowdfunding”, Venture Capital, Vol. 15 No. 4, pp. 335-359.

Wynn, D.C. and Clarkson, P.J. (2018), "Process models in design and development", Research in Engineering Design, Vol. 29 No. 2, pp. 161-202. https://doi.org/10.1007/s00163-017-0262-7 